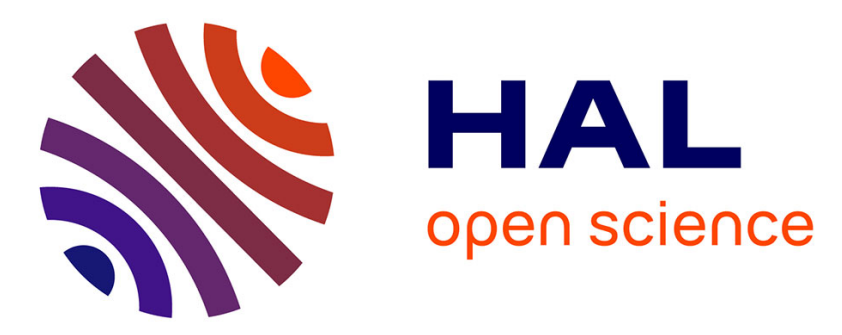

\title{
A study of rotating stall in a vaneless diffuser of radial flow pump
}

\author{
Yaguang Heng, Antoine Dazin, Mohamed Najib Ouarzazi, Qiaorui Si
}

\section{To cite this version:}

Yaguang Heng, Antoine Dazin, Mohamed Najib Ouarzazi, Qiaorui Si. A study of rotating stall in a vaneless diffuser of radial flow pump. Journal of Hydraulic Research, 2018, 56 (4), pp.494-504. 10.1080/00221686.2017.1399934. hal-02140401

\section{HAL Id: hal-02140401 \\ https://hal.science/hal-02140401}

Submitted on 27 May 2019

HAL is a multi-disciplinary open access archive for the deposit and dissemination of scientific research documents, whether they are published or not. The documents may come from teaching and research institutions in France or abroad, or from public or private research centers.
L'archive ouverte pluridisciplinaire HAL, est destinée au dépôt et à la diffusion de documents scientifiques de niveau recherche, publiés ou non, émanant des établissements d'enseignement et de recherche français ou étrangers, des laboratoires publics ou privés. 


\section{A Study of Rotating Stall in a Vaneless Diffuser of Radial Flow Pump}

Yaguang HENG, PhD student

Laboratoire de Mécanique de Lille

FRE CNRS 3723

Arts et Métiers Paristech,

8 Boulevard Louis, Lille 59046, France

E-mail: hengyaguang@gmail.com

Antoine DAZIN, Professor

Laboratoire de Mécanique de Lille

FRE CNRS 3723

Arts et Métiers Paristech,

8 Boulevard Louis, Lille 59046, France

E-mail: antoine.dazin@ensam.eu (author for correspondence)

Mohamed Najib OUARZAZI, Professor

Laboratoire de Mécanique de Lille

FRE CNRS 3723

Université Lille 1,

59650 Villeneuve-d'Ascq, France

E-mail:najib.ouarzazi@univ-lille1.fr

Qiaorui SI, Assistant Professor

National Research Center of Pumps,

Jiangsu University,

Zhenjiang City 212013, China

E-mail: siqiaorui@gmail.com 


\title{
A Study of the Rotating Stall in a Vaneless Diffuser of Radial Flow Pump
}

\begin{abstract}
Rotating stall in a vaneless diffuser of radial flow pump is studied. The measurements have consisted of: i/ unsteady pressure measurements delivered by two microphones, ii/ 9 steady pressure taps mounted in one radial line to measure the pressure recovery in the vaneless diffuser. Spectrum analysis was used to identify and characterize rotating stall. An assumption was made to estimate the losses in the vaneless diffuser to evaluate the effect of the instability development on its performance. The result has shown that the arising of rotating stall has a positive effect on the diffuser performance. Two possible reasons are proposed: 1 . A blockage in the diffuser due to the unstable cells which shortens the streamlines and decreased the friction losses along the vaneless diffuser. 2. The topology of rotating stall cells results in the convection of fluid coming from outside part of the pump model to the vaneless diffuser.
\end{abstract}

Keywords: Experimental research, Diffuser performance, Radial pump, Rotating stall, Spectrum analysis, Vaneless diffuser

\section{Introduction}

Pumps are widely used in many fields, like irrigation, water supply, cooling system, pumping station, etc (Mahdi \& Bryan, 2008). One important limit in the operating range of pumps is the occurrence of unstable phenomena in their internal flows. One of them is the rotating stall which is occurring in diffusers of radial flow pumps operating at partial flow rates (Dazin et al., 2008, 2011). Several negative effects are also associated with rotating stall, such as noise, vibration, mechanical damage and especially performance reduction. Therefore, characterizing, understanding and even predicting this phenomenon is important and necessary. A lot of studies of rotating stall have thus been carried out and the research methods could be summarized as follows:

(1) Theoretical analysis, which includes three dimensional analysis (Jansen, 1964; Senoo, Kinoshita, \& Ishida, 1977; Senoo \& Kinoshita, 1977; Fringe \& Van den Braembussche, 1985; Dou \& Mizuki, 1998) and two dimensional analysis (Tsujimoto, Yoshida, \& Mori, 1996; Moore, 1989; Abdelhamid, 1980). For two dimensional analysis, it is generally admitted that the effect of boundary layer can be ignored in wide vaneless diffuser, for which the existence of a $2 \mathrm{D}$ core flow is assumed, as shown in Fig. 1. On the other hand, the effect of three-dimensional boundary layer 
instability was suggested to be responsible for the occurrence of rotating stall in the narrow vaneless diffuser.

(2) Experimental researches (for example: PIV study-Wuibaut, Dupont, Bois, Caignaert, \& Stanislas, 2002; Krause, Zähringer, \& Pap, 2005; Pavesi et al., 2011; Dazin et al., $2008,2011)$ and numerical analyses are quite numerous in open literature. The main research contents of rotating stall were focused on several aspects:

i. The effect of flow conditions and geometries of impeller/diffuser on the rotating stall, such as diffuser width (Senoo \& Kinoshita, 1977; Abdelhamid \& Bertrand, 1979; Ötügen, So, \& Hwang, 1988; Ljevar, 2007; Ferrara, Ferrari, \& Baldassarre, 2004; Abidogun, 2006; Nishida \& Kobayshi, 1988), coupling between impeller and diffuser (Abdelhamid, 1980; Ferrara, Ferrari, \& Baldassarre, 2004; Kobayshi \& Nishida, 1990), diffuser diffusion ratios (Ferrara, Ferrari, \& Baldassarre, 2004), Mach number (Senoo \& Kinoshita, 1977; Ferrara, Ferrari, \& Baldassarre, 2004), Reynolds number (Senoo \& Kinoshita, 1977; Abidogun, 2006), radius ratios of diffuser (Senoo \& Kinoshita, 1977; Abdelhamid \& Bertrand, 1979; Abdelhamid, 1981; Ljevar et al., 2006, 2007; Abidogun, 2006), impeller (Ljevar et al., 2006, 2007; Abidogun, 2006).

ii. The prediction, detection and control of the inception of rotating stall (Tsurusaki, Imaichi, \& Miyake, 1987; Tsurusaki \& Kinoshita, 2000; Kurokawa, Saha, Matsui, \& Kitahora, 1999).

iii. Analysis of the characteristics of rotating stall itself: such as the critical flow angle, propagation velocity, frequency and number of stall cells (Cellai, Ferrara, Ferrari, Mengoni, \& Baldassarre, 2003; Dazin et al., 2008, 2011; Pavesi et al., 2011; Suzuki, Ugai, \& Harada, 1977; Caignaert, Desmet, \& Stevenaert, 1982; Abdelhamid, Colwill, \& Barrows, 1979).

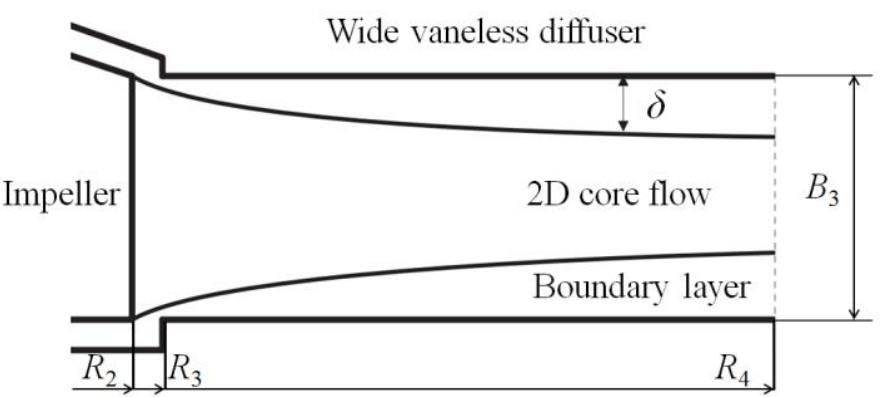

Figure 1 The flow structure in wide vaneless diffuser (Ljevar, 2007)

Although rotating stall was studied in many aspects listed above, some of the mechanisms and effects of the instability are still unclear. Therefore, the present work reports studies managed with the support of an experimental test rig which was used to observe the rotating stall in the vaneless diffuser. 22 flow rates were tested for two rotating speed: 1200 
and 1800 RPM. A dedicated spectrum analysis was applied to spectrally identify and characterize the rotating modes which were observed in the vaneless diffuser: number of cells, amplitude and propagation velocity of the stall. At last, an analysis of the pressure losses in the diffuser operating in stable or unstable conditions is proposed to study the effect of rotating stall on the performance of such a wide vaneless diffuser.

\section{Experiment Apparatus}

The experimental test rig (Fig. 2) includes a radial impeller which was coupled with a vaneless diffuser. Inlet conditions are obtained using a long suction pipe. In order to ensure axisymmetric outlet boundary conditions, no volute was set downstream to the vaneless diffuser. The configuration was equipped with 9 steady pressure taps which were flush mounted on the diffuser wall in one radial line (equally spaced from $R=264 \mathrm{~mm}$ to $384 \mathrm{~mm}$ ). Therefore, the diffuser performance is determinable based on the pressure recovery from diffuser inlet to outlet. The uncertainty of these measurements was $\pm 2 \mathrm{~Pa}$. To ensure the stability of the inlet flow, a tank, equipped with a honeycomb flow straightener, was set before the suction pipe. A set of changeable diaphragms (with different inlet diameters) is available to be installed at the tank inlet to adjust the flow rate.

Two Brüel \& Kjaer condenser microphones (Type 4135) were used to get the unsteady pressure fluctuation. They were flush mounted at the same radius $(R=320 \mathrm{~mm})$ on the diffuser wall but with an angular difference of $\Delta \theta=75^{\circ}$, then the instabilities which occurred in the vaneless diffuser are detectable and analyzable. The measurement uncertainty for these measurements was less than $1 \%$. The data were acquired by LMS. Test Xpress with the sampling time 600 seconds and sampling frequency $4096 \mathrm{~Hz}$.

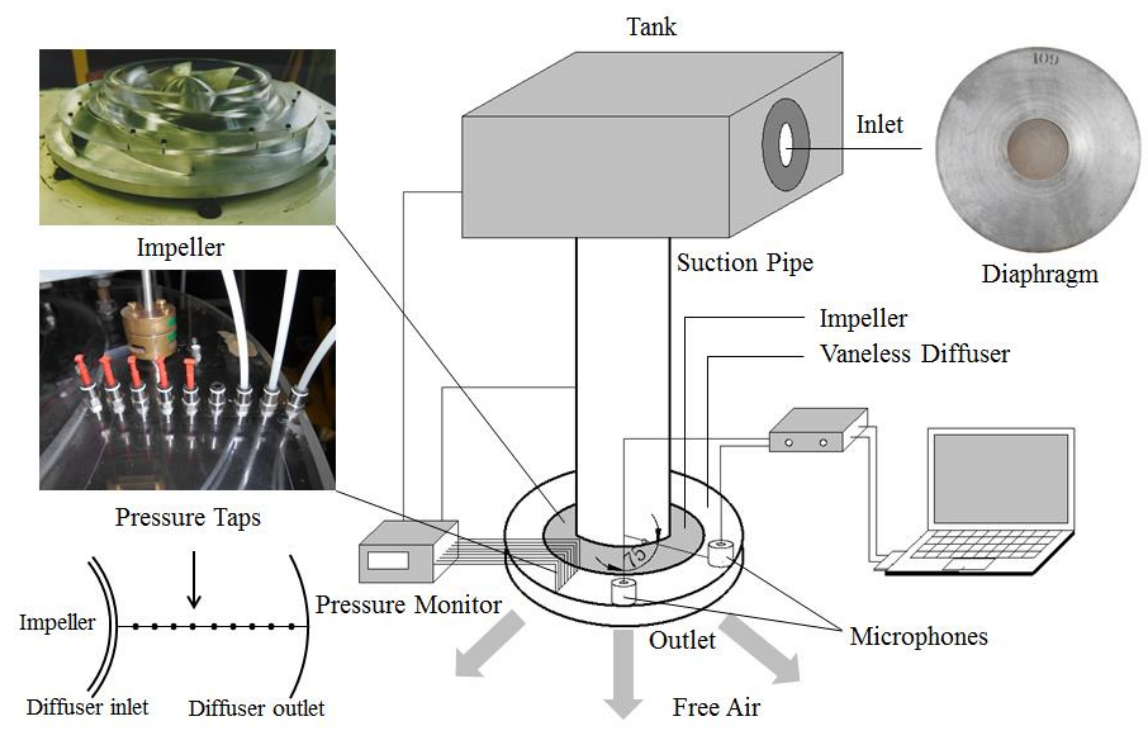

Figure 2 Experimental test rig 
Table 1 Main parameters of impeller and vaneless diffuser

\begin{tabular}{lll}
\hline Impeller & & \\
\hline$D_{1}$ & Inlet Diameter & $282.2(\mathrm{~mm})$ \\
$D_{2}$ & Outlet Diameter & $513.2(\mathrm{~mm})$ \\
$B_{2}$ & Impeller Outlet Width & $38.5(\mathrm{~mm})$ \\
$Z$ & Number of Blades & 7 \\
$\beta_{2}$ & Outlet Blade Angle & $22.5\left(^{\circ}\right)$ \\
$Q_{\mathrm{d}}$ & Design Flow Rate $(N=1200 \mathrm{RPM})$ & $0.236\left(\mathrm{~m}^{3} \mathrm{~s}^{-1}\right)$ \\
\hline Vaneless Diffuser & & \\
\hline$D_{3}$ & Inlet Diameter & $514.2(\mathrm{~mm})$ \\
$D_{4}$ & Outlet Diameter & $768.0(\mathrm{~mm})$ \\
$B_{3}$ & Diffuser Width & $38.5(\mathrm{~mm})$ \\
$R_{\mathrm{e}}=\rho V_{3} B_{3} / \mu$ & Reynolds Number & $4.54 \times 10^{4}$ \\
& $\left(Q / Q_{\mathrm{d}}=1.0, N=1200 \mathrm{RPM}\right)$ &
\end{tabular}

The experiment was made in air, and the main parameters of radial impeller and vaneless diffuser are given in Table 1 . In this experiment, 22 flow rates $\left(Q / Q_{\mathrm{d}}=0.26 \rightarrow 1.53\right)$ were performed for two rotating speeds: 1200 RPM and 1800 RPM. The pump (impeller + diffuser) and the diffuser performances (in terms of static pressure rise) are plotted in Fig. 3. More details of this experimental test rig can be found in previous studies presented by Dazin et al. $(2008,2011)$ with the same configuration.

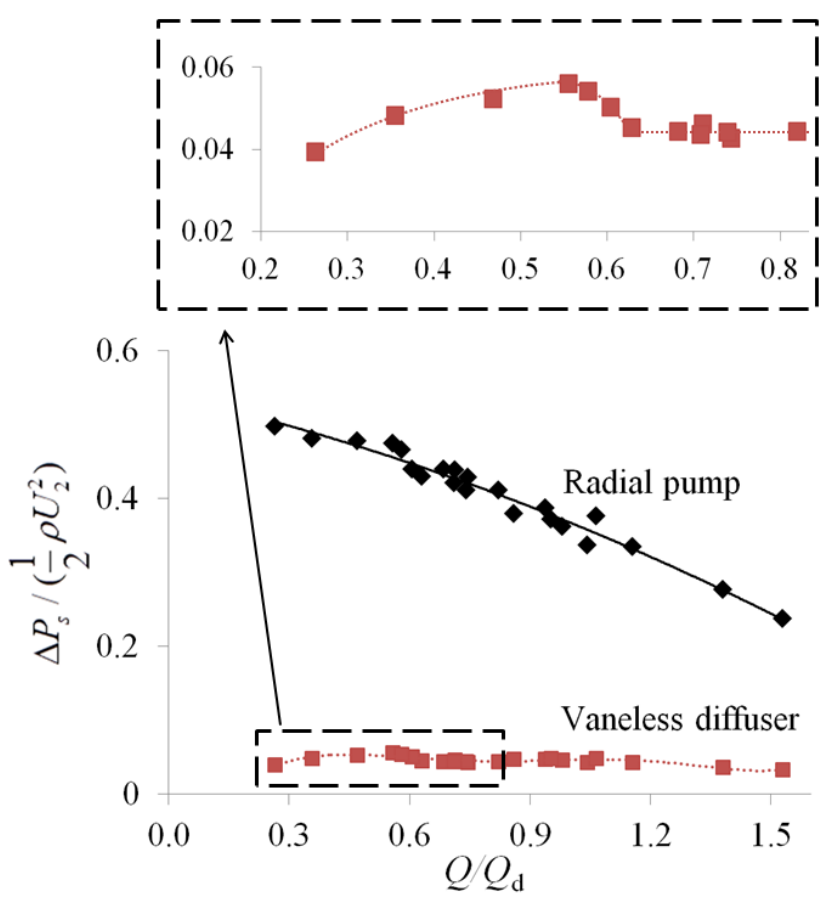

Figure 3 Pump and diffuser performance curves. (Static pressure rise) 


\section{Experimental results}

\subsection{Characteristics of rotating stall}

The spectrum information which was acquired by two microphones allows to detect the development of rotating stall in the vaneless diffuser and also to analyze its characteristics, as shown in Fig. 4, where $\psi$ was defined as:

$$
\psi=\frac{P}{\rho U_{2}^{2}}
$$

Where $P$ is the microphone pressure signal.

(a)

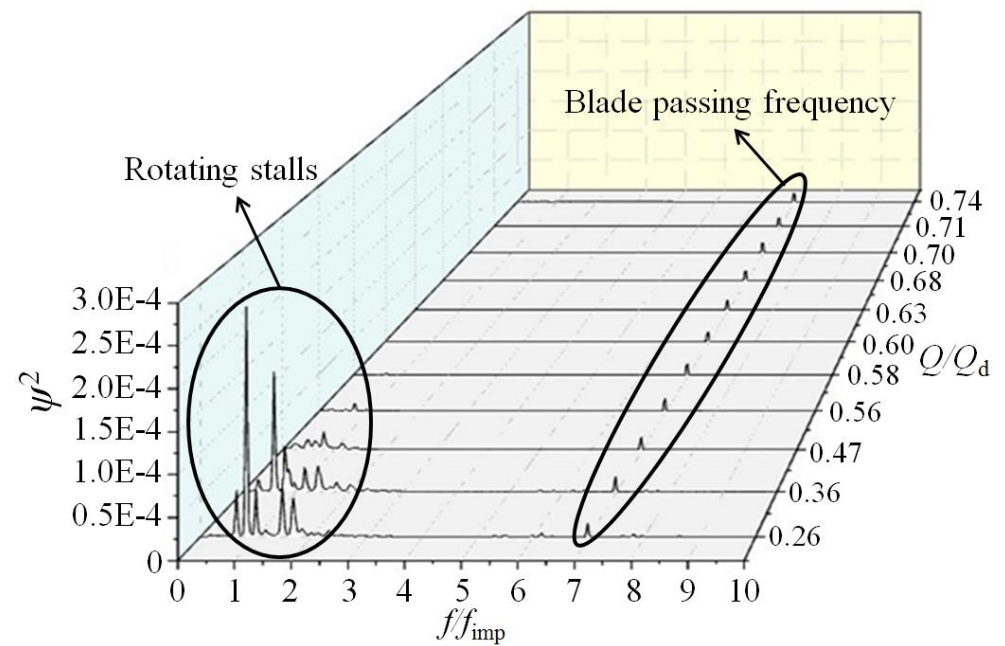

(b)

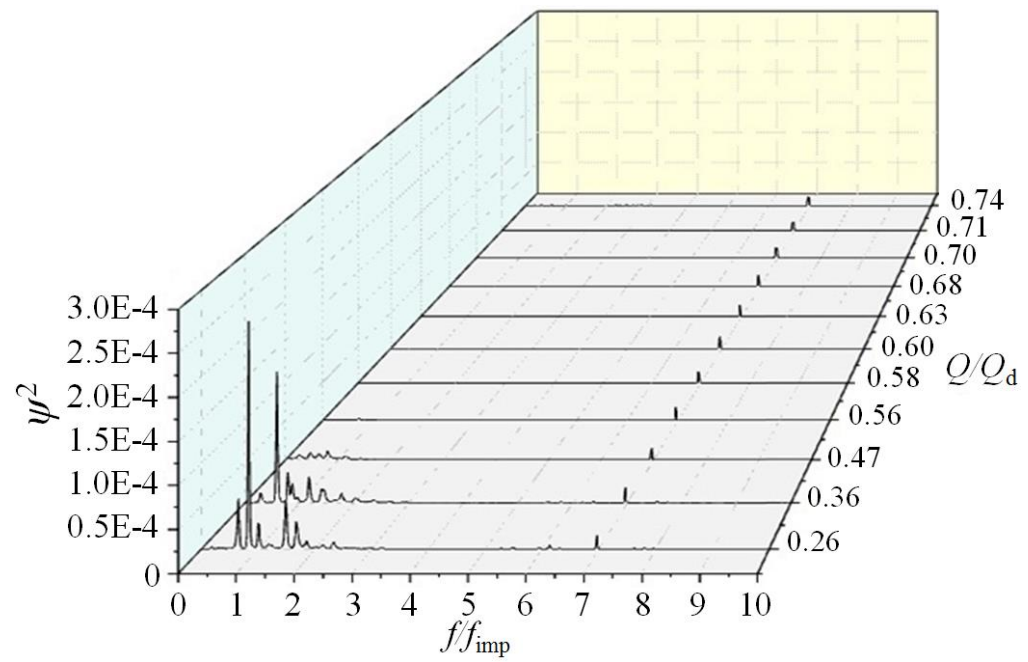

Figure 4 Crosspower spectra at two impeller angular velocities: (a) 1200 RPM and (b) 1800 RPM 
According to the spectrum analysis, rotating stall was identified at the five partial flow rates: $Q / Q_{\mathrm{d}}=0.26,0.36,0.47,0.56,0.58$, and cannot be observed when the flow rate ratio is higher than 0.6. For a given flow rate, rotating stall characteristics are similar for the two rotating speeds investigated.

When the flow rate ratio is higher than 0.6 , the dominant frequency was the blade passing frequency (a typical example is proposed Fig. 5a), and the impeller frequency and its harmonics are also significant. On the contrary, for the five lower partial flow rates, the spectra are dominated by several low frequency peaks due to rotating stall, as shown in Fig. $5 b, c, d, e$ and $f$.

(a)

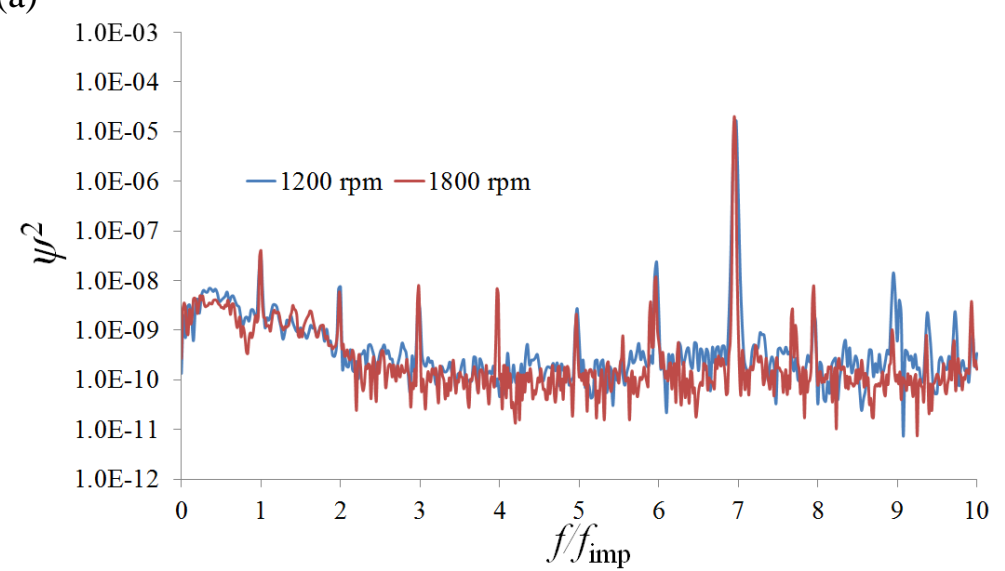

(b)

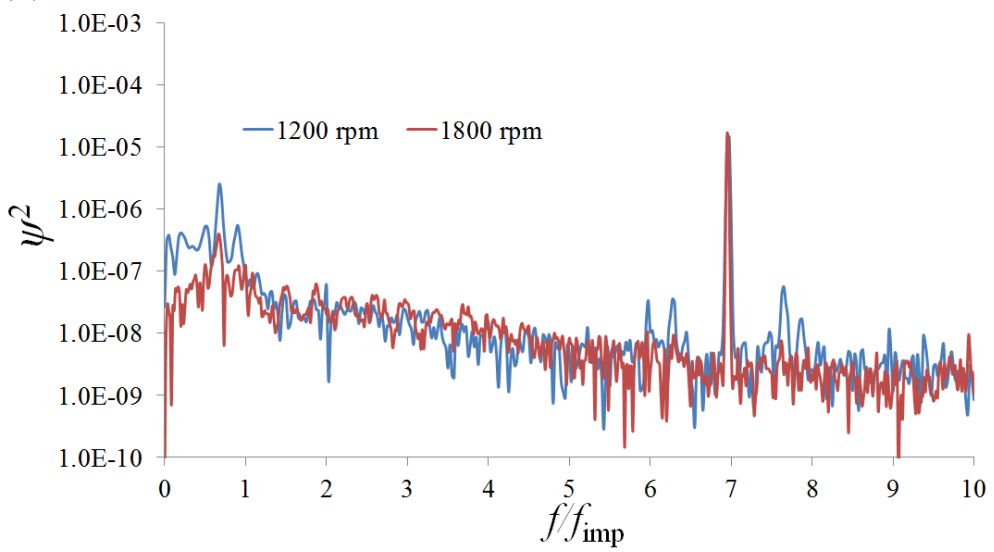

(c)

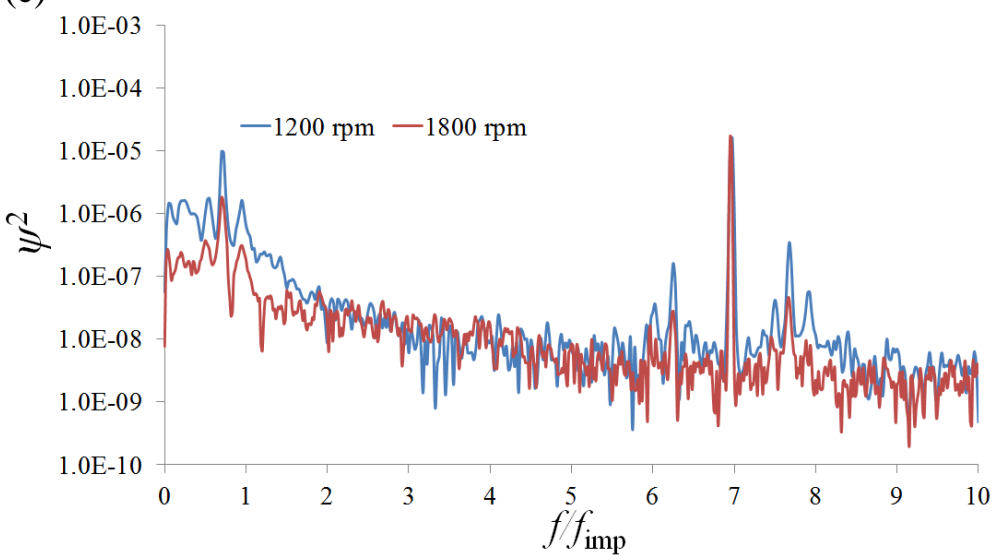


(d)

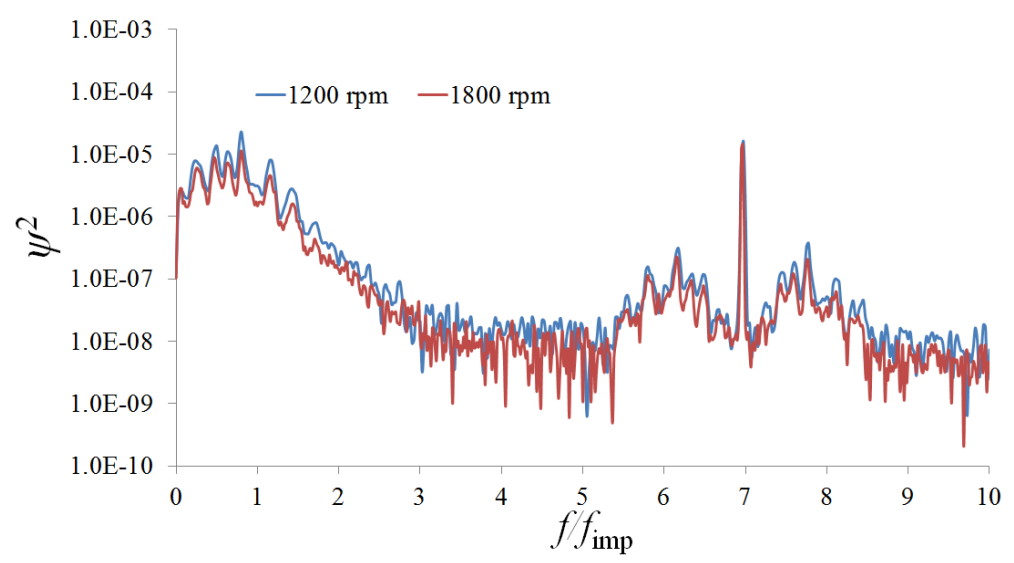

(e)

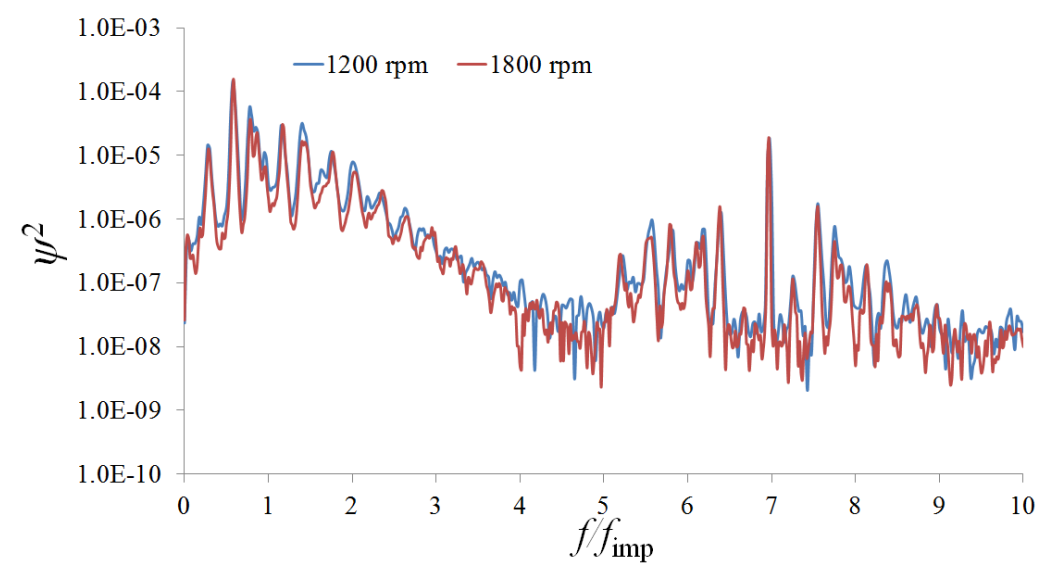

(f)

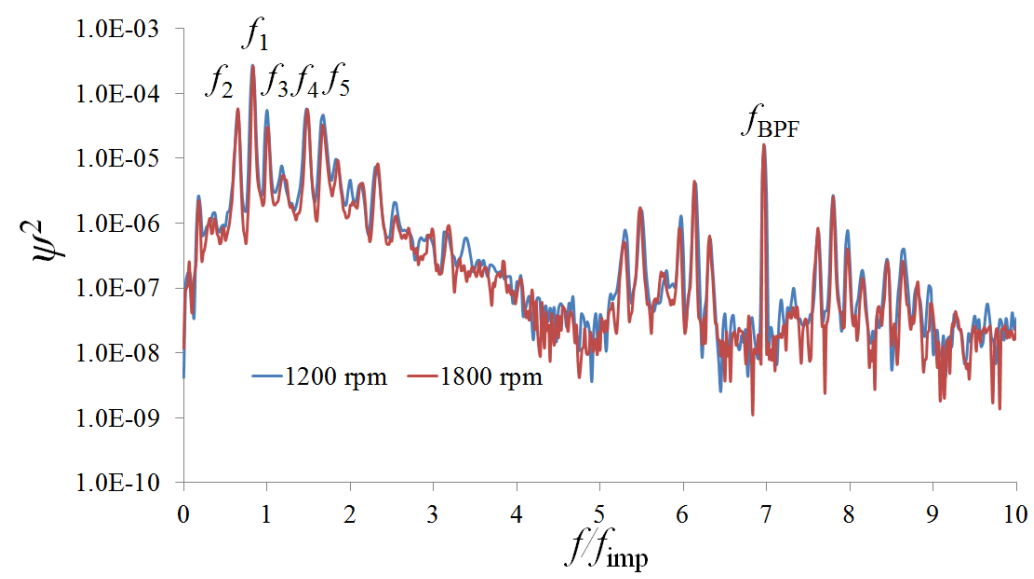

Figure 5 Crosspower spectra at design flow rate (a) and the flow rates with rotating stall: (b)

$$
Q / Q_{\mathrm{d}}=0.58 \text {; (c) } Q / Q_{\mathrm{d}}=0.56 \text {; (d) } Q / Q_{\mathrm{d}}=0.47 \text {; (e) } Q / Q_{\mathrm{d}}=0.36 \text {; (f) } Q / Q_{\mathrm{d}}=0.26
$$

At one flow condition, some peaks may correspond to different modes of rotating stall, but others to harmonics or nonlinear interaction of fundamental phenomena. Therefore, a dedicated spectrum analysis was applied to identify the different modes of rotating stall. Considering the amplitude of each frequency from high to low, an example for flow rate $Q / Q_{\mathrm{d}}=0.26$ (Fig. 5f) is given in Table 2. As the pressure fluctuation signal associated with one 
stall mode $n$ is assumed to be $\tilde{p}=p_{0}(r) \cdot \cos (n(\omega t-\theta))$. The determination of number of stall cells $n$ depends on the measured phase difference between the two microphones $\Delta$ phase and the angular difference $\Delta \theta$ between them, that is: $n=\Delta$ phase $/ \Delta \theta$.

Table 2 Rotating stalls, harmonics and nonlinear interaction at flow rate $Q / Q_{\mathrm{d}}=0.26$

\begin{tabular}{ccc}
\hline Frequency $(\mathrm{Hz})$ & Amplitude $\left(\mathrm{Pa}^{2}\right)$ & Mode \\
\hline$f_{1}=16.5$ & 410.1 & Stall mode 1 \\
$f_{2}=13$ & 87.2 & Stall mode 2 \\
$f_{3}=20$ & 82.6 & Impeller frequency \\
$f_{4}=29.5$ & 82.1 & Nonlinear interaction $\left(=f_{1}+f_{2}\right)$ \\
$f_{5}=33$ & 69.8 & Harmonic $\left(=2 f_{1}\right)$ \\
\hline
\end{tabular}

As it can be seen from Table 2, two frequencies corresponding to different rotating stall modes can be identified. It has been shown in a previous study (Pavesi et al, 2011) that for a given operating point, two stall modes can coexist intermittently. A synthesis of the unstable modes that can be evidenced for each flow rates is proposed in Table 3, in which $n$ is the number of rotating cells that could be identified through the analysis of the phase difference of the pressure signals of the two microphones.

Table 3 Different modes of rotating stall

\begin{tabular}{ccccc}
\hline$Q / Q_{\mathrm{d}}$ & Dominant & Second & Third & Fourth \\
\hline 0.26 & $n=3$ & $n=2$ & no & no \\
0.36 & $n=2$ & $n=3$ & no & no \\
0.47 & $n=4$ & $n=2$ & $n=3$ & no \\
0.56 & $n=4$ & no & no & no \\
0.58 & $n=4$ & no & no & no \\
\hline
\end{tabular}

It can be seen that with the flow rate decrease, the dominant stall mode starts from 4 cells mode $\left(Q / Q_{\mathrm{d}}=0.47,0.56,0.58\right)$, then becomes 2 cells mode $\left(Q / Q_{\mathrm{d}}=0.36\right)$, and changes to 3 cells mode $\left(Q / Q_{\mathrm{d}}=0.26\right)$ at last. This trend agrees well with previous study on the same experimental configuration (Dazin et al., 2008). Based on the rotating stall frequency, the circumferential velocity of the stall cells $\omega$, can be estimated as follow:

$$
\omega=2 \pi \bullet f_{r s} / n
$$

Then the amplitude and dimensionless circumferential velocity of stall cells versus flow rate are drawn in Fig. 6. Concerning the amplitude, the general tendency is an increase of the intensity of the unstable flow with the flow rate decrease. It can be seen that the circumferential velocity of stall cells is increasing with the decrease of flow rate. This can be 
linked with the increase of the circumferential velocity of the main flow with the decrease of flow rate according to the shape of the velocity triangle at impeller outlet (diffuser inlet), then the circumferential velocity of rotating stall which is involved in the diffuser flow is then increased. This tendency can also be found in a theoretical work presented by Tsujimoto, Yoshida, \& Mori (1996).

(a)

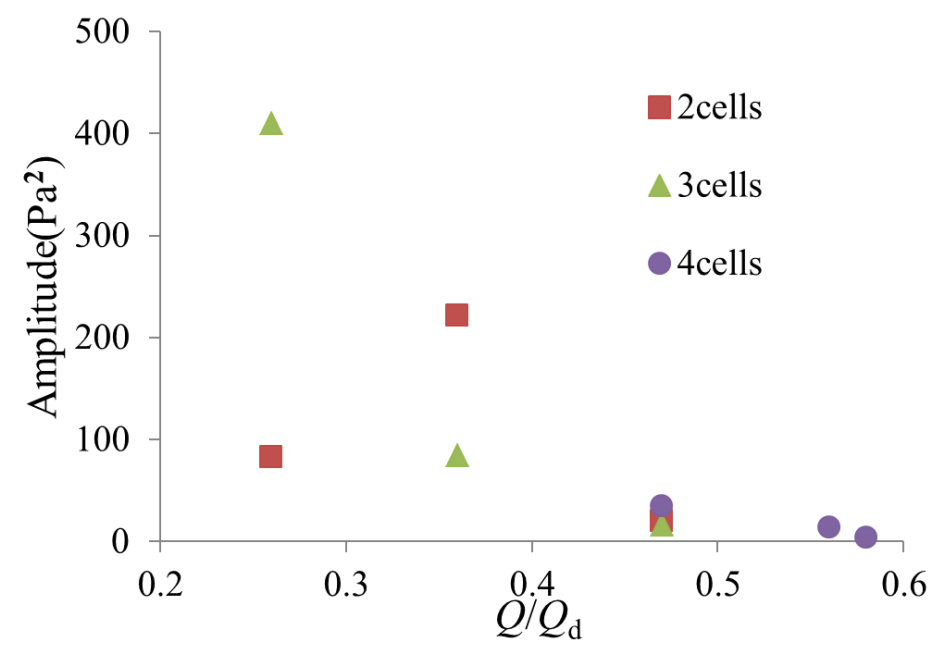

(b)

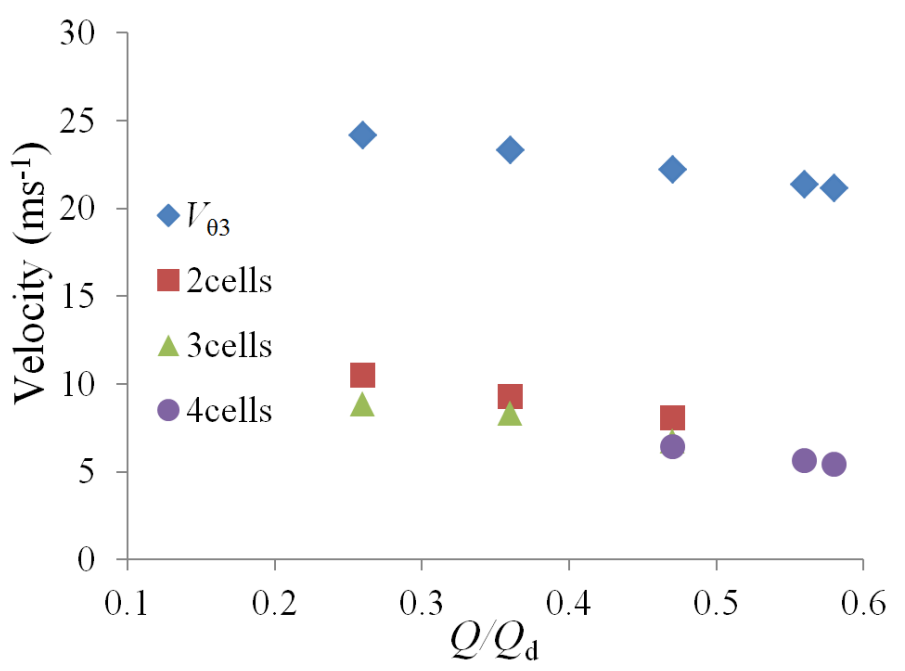

Figure 6 The amplitude (a) and circumferential velocity (b) of stall cells for 1200 RPM

\subsection{Effect of rotating stall on the diffuser performance}

Since the presence of rotating stall in the vaneless diffuser is confirmed and characterized, it is possible to determine the effect of rotating stall on the diffuser performance. Using the measured values of the 9 wall static pressure taps along the diffuser wall, the mean pressure evolution from diffuser inlet to outlet can be obtained. Figure 7 gives the pressure recovery in the vaneless diffuser, scaled by the kinetic energy at the diffuser inlet. The absolute velocity 
at diffuser inlet has been evaluated by the determination of the velocity triangle at impeller outlet.

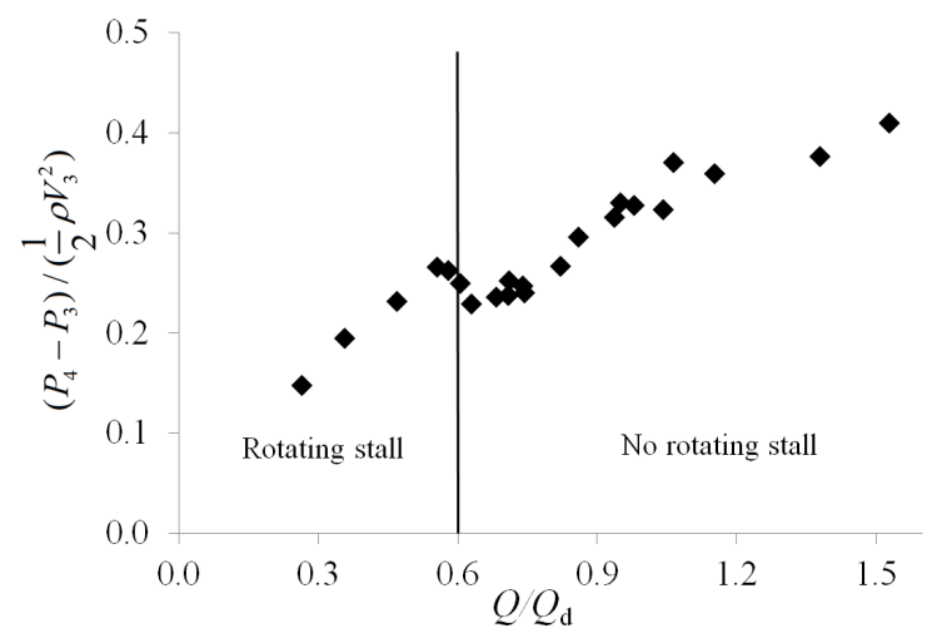

Figure 7 Diffuser static pressure recovery versus flow rate ratio

In stable conditions (with no rotating stall), it can be seen that the diffuser performance is decreased with the flow rate, but is increased at the onset of rotating stall and then decreased again when rotating stall is fully developed. One can note that the performance increase is also obvious on the performance curve of the diffuser (Fig. 3), around $Q / Q_{\mathrm{d}}=0.6$.

To study more accurately the effect of rotating stall on the diffuser performance, an analysis of the losses in the diffuser is proposed: the isentropic increase of pressure due to the velocity decrease in the diffuser has been calculated and compared to the experimental pressure recovery (Fig. 8): more precisely, at the diffuser outlet, the pressure difference between the isentropic theoretical estimation and the experimental result is then defined as experimental losses, and an experimental loss coefficient can be defined as:

$$
\varepsilon=\operatorname{Losses} /\left(\rho \frac{V_{3}^{2}}{2}\right)
$$

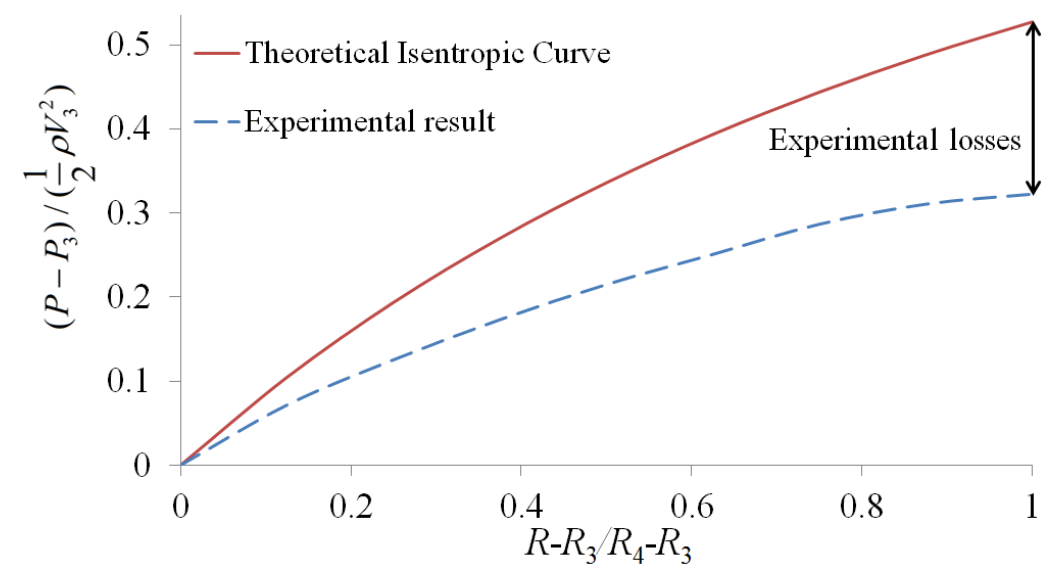

Figure 8 Pressure recovery curve at design flow rate $Q_{\mathrm{d}}$ 
The losses in vaneless diffuser, in stable operations, are usually divided into three terms: $\mathrm{i}$ / losses due to friction that can be modeled by a friction factor derived from the ones obtained in duct flows. ii/ Additional losses due to the adverse pressure gradient. These losses are commonly called 'diffusion losses'. iii/ Losses due to the mixing of the jet wake pattern coming out from the impeller.

The present study is neglecting the two last losses sources because:

ii/ the diffusion losses could be neglected if the streamline in the diffuser is sufficiently long (Aungier, 1993; Dou, 1991). Dou (1991) showed that the diffusion losses could be neglected for diffuser width of the same order of magnitude compared to the one used in the present study $\left(B_{3} / D_{2}=0.075\right)$ if the absolute flow angle at diffuser inlet is lower than $25^{\circ}$. In the present study, the diffuser inlet flow angle varies from $2.3^{\circ}$ to $24.6^{\circ}$, depending on the flow rate studied.

iii/ The mixing losses are concentrated in the region close to the impeller outlet $\left(1.00<D / D_{2}<1.06\right)$ (Dou, 1991). In the present paper, the first pressure tap is located at $D / D_{2}=1.09$ and the effect of the mixing losses in the performance of the diffuser has not to be taken into account in the analysis of the pressure recovery curves presented.

Consequently, if the vaneless diffuser is on stable operation, the losses are supposed to be mainly due to friction losses along the length $L$ of a streamline:

$$
\text { Losses }=\frac{\lambda}{D_{\mathrm{H}}} \rho \frac{V_{3}^{2}}{2} L
$$

Where $D_{\mathrm{H}}$ is the hydraulic diameter, $\lambda$ is the friction factor, and in the present vaneless diffuser,

$$
D_{H}=\frac{4 S}{C}
$$

Where $S$ is the cross sectional area which is equal to $2 \pi \bar{r}^{*} B_{3}$, and $C$ is the perimeter of the cross-section which is equal to $4 \pi \bar{r}$.

The diffuser loss coefficient in stable conditions is:

$$
\varepsilon_{S}=\operatorname{Losses} /\left(\rho \frac{V_{3}^{2}}{2}\right)=\frac{\lambda}{D_{H}} \bullet L
$$

Which is depending only on the length of streamline $L$, and the streamline in the vaneless diffuser is known as a logarithmic spiral (Fig. 9) (from the continuity equation and moment of momentum equation, and assuming that the flow is $2 \mathrm{D}$, axisymmetric). The length of streamline $L$ can be estimated by equation (7). It is depending only on the value of the 
absolute flow angle $\alpha$ at diffuser inlet and is thus increasing with the flow rate decrease, as shown in Fig. 10.

$$
L=a \sec \left(\alpha+\frac{\pi}{2}\right)\left(e^{\theta \cot \left(\alpha+\frac{\pi}{2}\right)}-1\right)
$$

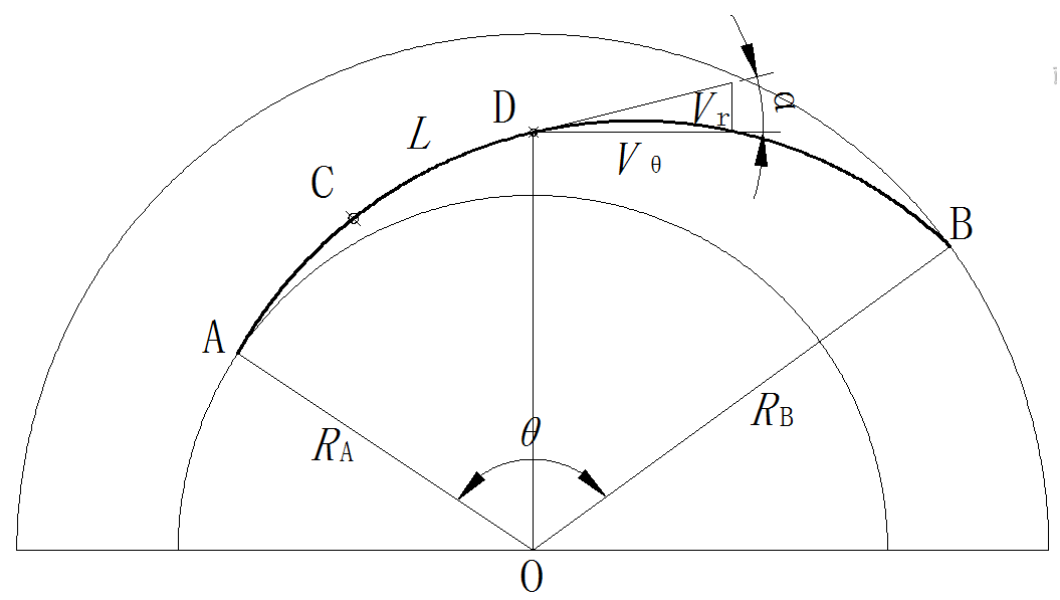

Figure 9 Streamline in the vaneless diffuser

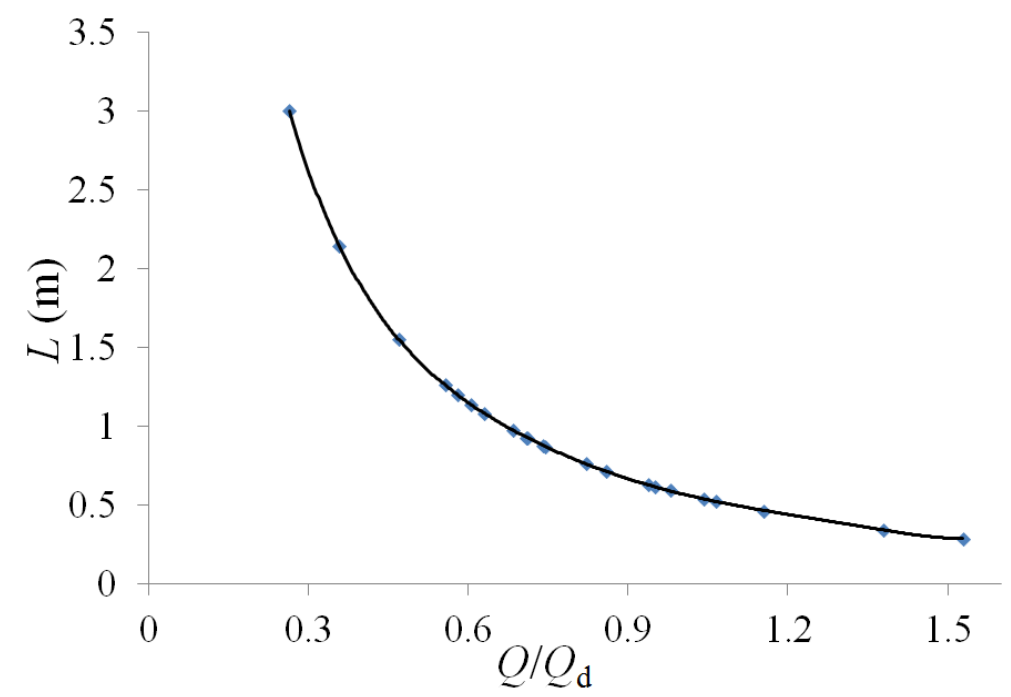

Figure 10 Length of streamline versus flow rate

The diffuser inlet flow angle was estimated from the calculation of the velocity triangle at impeller outlet, using Stodola slip factor. The evolution of the diffuser loss coefficient versus the length of streamline was drawn in Fig. 11. It can be seen that the losses increase linearly with the streamline length for small value of $L$, that is, for operating conditions without rotating stall (stable conditions). Moreover, it is noticeable that the experimental slope $(\approx 0.32)$ is close to the theoretical one $\lambda / D_{H}(=0.28$, with a value of the friction factor extracted from the Moody diagram), as it was assumed in equation (6). What is 
particularly notable in Fig. 11 is that the arising of rotating stall is corresponding to a clear drop of the losses. This is confirmed again in Fig. 12, presenting the evolution of the loss coefficient as a function of the flow rate. In this figure, the loss coefficient drops at the arising of rotating stall is also obvious. After this drop, the losses are increasing again with the decreasing of flow rate, but this time with a clear much smaller slope than the one $\left(\varepsilon_{S}\right)$ calculated based on the length of logarithmic spiral which represents the conditions without rotating stall.

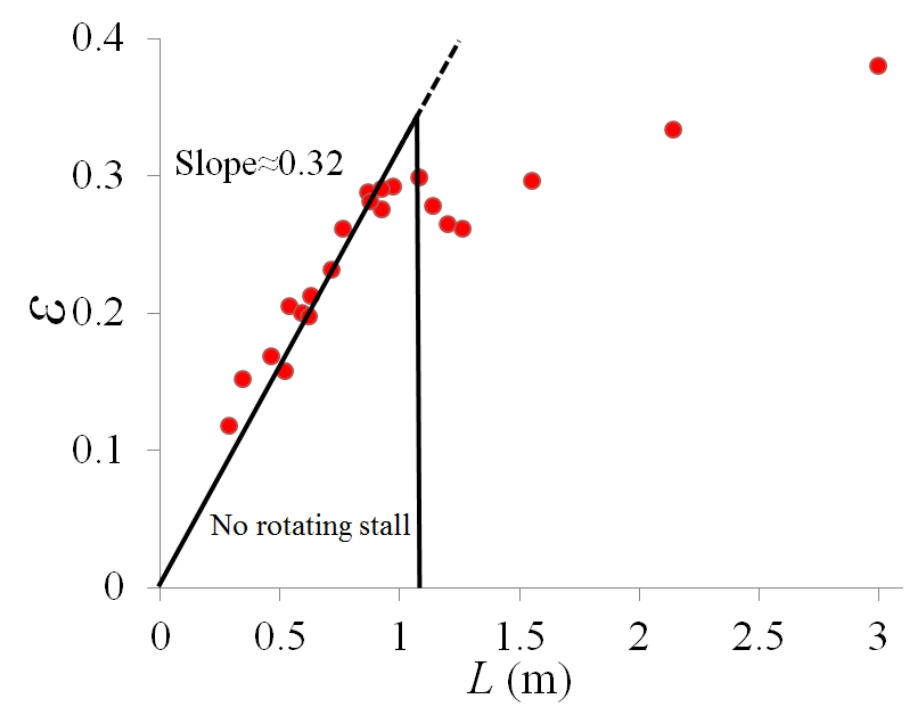

Figure 11 Diffuser loss coefficient at diffuser outlet versus length of streamline

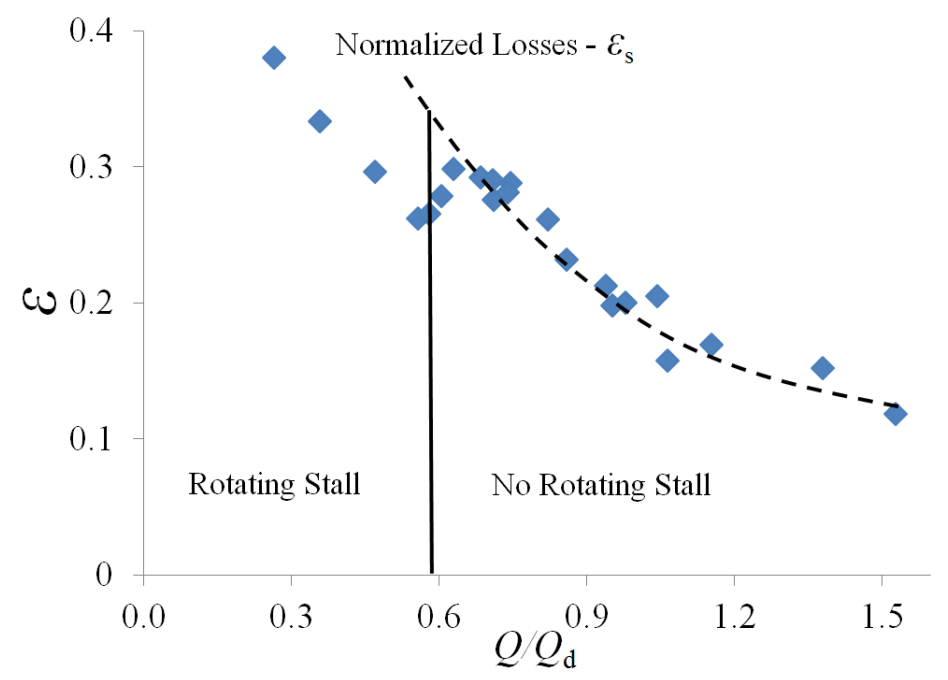

Figure 12 Losses at diffuser outlet versus flow rate ratio $Q / Q_{\mathrm{d}}$ 


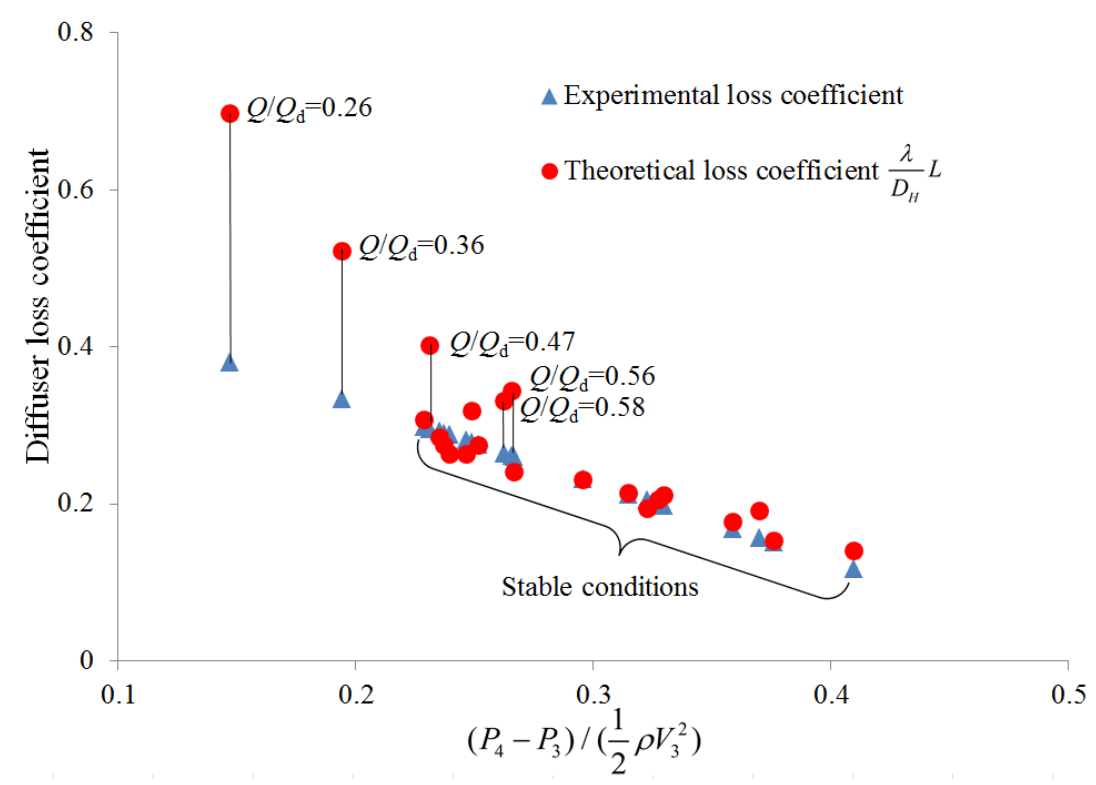

Figure 13 Diffuser losses coefficient versus the static pressure recovery coefficient

Figure 13 gives the diffuser experimental/theoretical losses coefficient versus the static pressure recovery coefficient. The experimental loss coefficient is a straight line. This is due to the definition of the experimental losses which are defined as the difference between the isentropic pressure recovery and the experimental pressure recovery. Consequently, the experimental loss coefficient is:

$$
\varepsilon=\frac{\left(P_{4 i s}-P_{3}\right)-\left(P_{4}-P_{3}\right)}{0.5 \rho V_{3}^{2}}
$$

That is:

$$
\varepsilon=\left(1-\frac{R_{3}^{2}}{R_{4}^{2}}\right)-\frac{\left(P_{4}-P_{3}\right)}{0.5 \rho V_{3}^{2}}
$$

The theoretical loss coefficient is calculated based on equation (6) which assumes that the diffuser flow is stable (without rotating stall). It can be seen that the experimental loss coefficient agrees well with the theoretical one while the diffuser flow is stable. However, with the presence of rotating stall $\left(Q / Q_{\mathrm{d}}<0.58\right)$, the experimental loss coefficient is not as large as the theoretical prediction, which confirmed the effect of rotating stall on the diffuser performance.

As a conclusion, it seems that the arising of the instability could be a way, for the flow, to reduce its losses when the flow angle is very low at diffuser inlet. The losses reduced means the diffuser performance with rotating stall is higher than the one without rotating stall because of the choice of the isentropic pressure curve that has been taken as a fixed theoretical value, as illustrated in Fig. 14. 


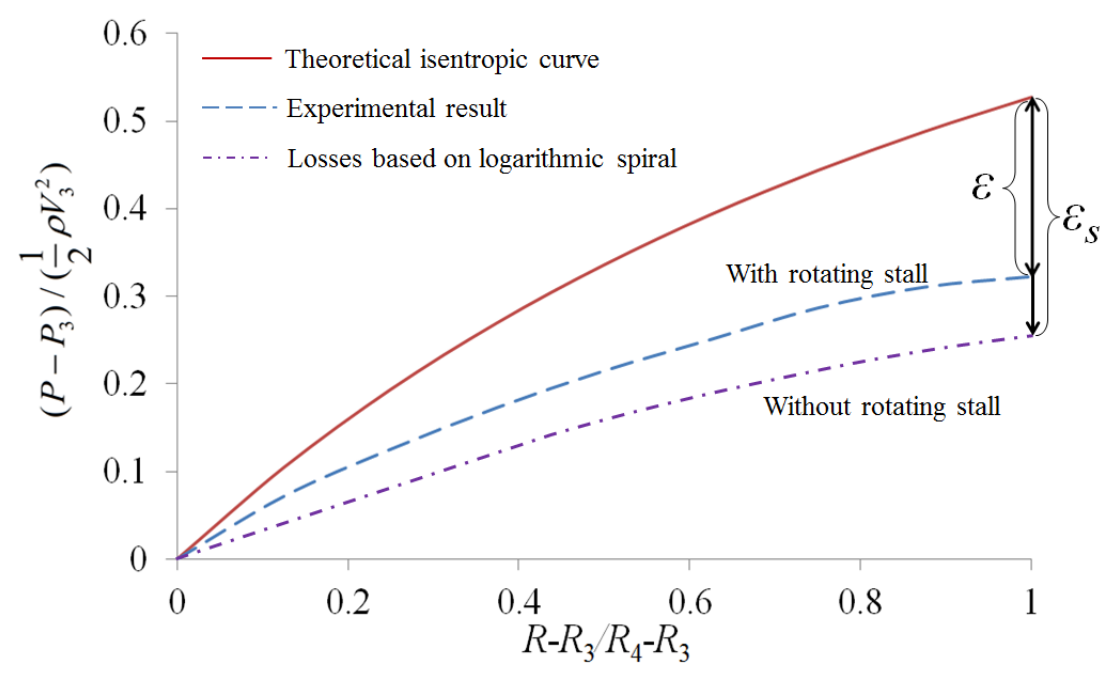

Figure 14 Diffuser pressure recovery

Two possible reasons may explain why the pressure recovery is increased in presence of rotating stall: First, Figure 15, from previous experimental study with the same configuration (Dazin et al., 2011), gives the PIV result of the radial velocity in the vaneless diffuser (at $Q / Q_{\mathrm{d}}=0.26$ ). Three rotating cells can be identified and each cell is composed of two cores with inward and outward radial velocity. Therefore, one can consider the rotating cells generate a blockage region due to the inward radial velocity near the diffuser outlet. Consequently, the flow in the regions outside of rotating cells is characterized by higher radial velocities than what we would have without rotating cells. Therefore, the real streamline could become shorter than the one we would have if the flow without rotating stall, and then the shorter streamline leads to smaller friction losses.

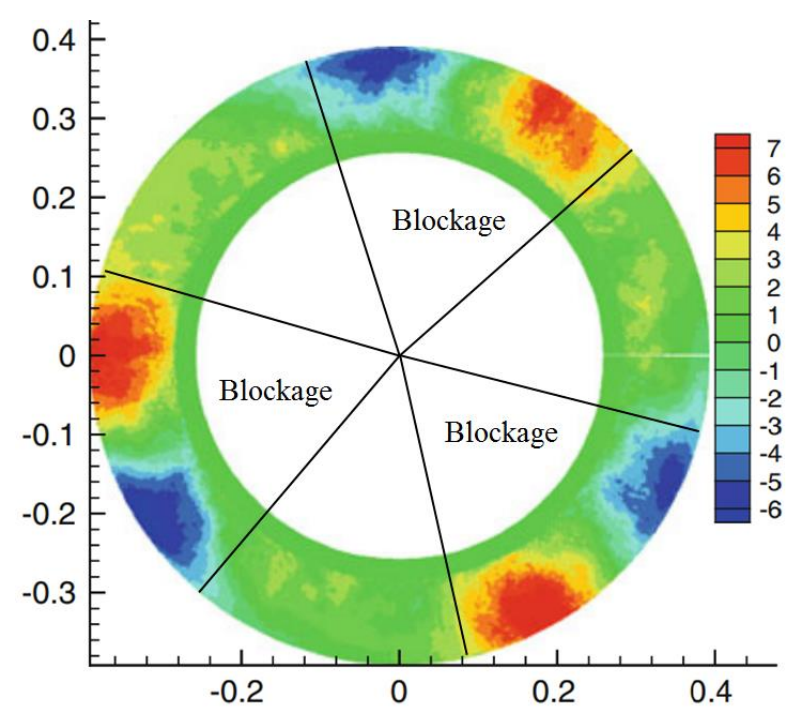

Figure 15 Radial velocity in the vaneless diffuser at $Q / Q_{\mathrm{d}}=0.26$ (Dazin et al., 2011) 
To estimate the streamline, previous PIV results were used to estimate the blockage induced by the rotating cells. Then, the vaneless diffuser can be divided into two parts, as shown in Fig. 16:

(1) Part 1: Before the streamline reaches to the boundary of cells, it can be assumed that the streamline is not affected by the presence of rotating stall.

(2) Part 2: After the streamline reaches to the stall zone, the effect of blockage due to stall cells should be taken into account.

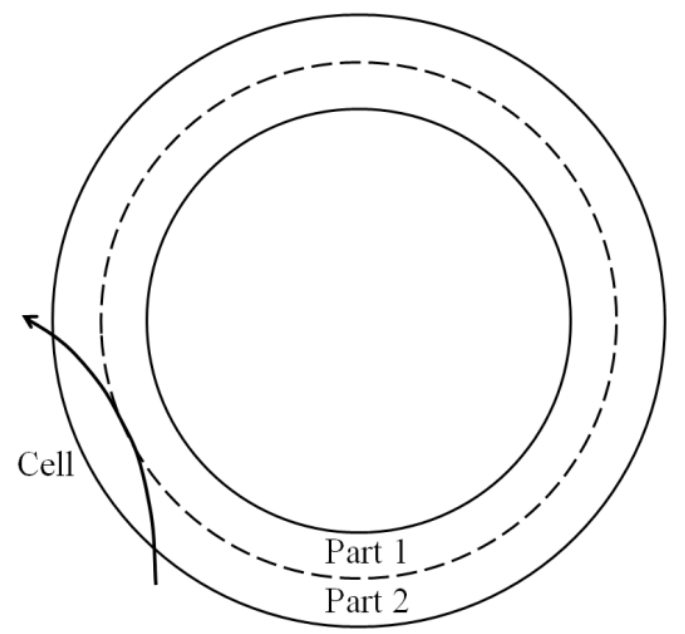

Figure 16 Two assumed spaces in the vaneless diffuser

Therefore, in Fig. 17, the length of streamline 1 has been calculated as before (without rotating stall). For the streamline 2, the new radial velocity has been calculated taking into account the blockage area identified from the PIV result. Then, a new flow angle and a new length of streamline 2 have been estimated. Finally, the new estimation of friction losses based on the new length of streamline has been calculated (with the same value of $\lambda / D_{H}$ used before) and compared with experimental results, as shown in Fig. 18.

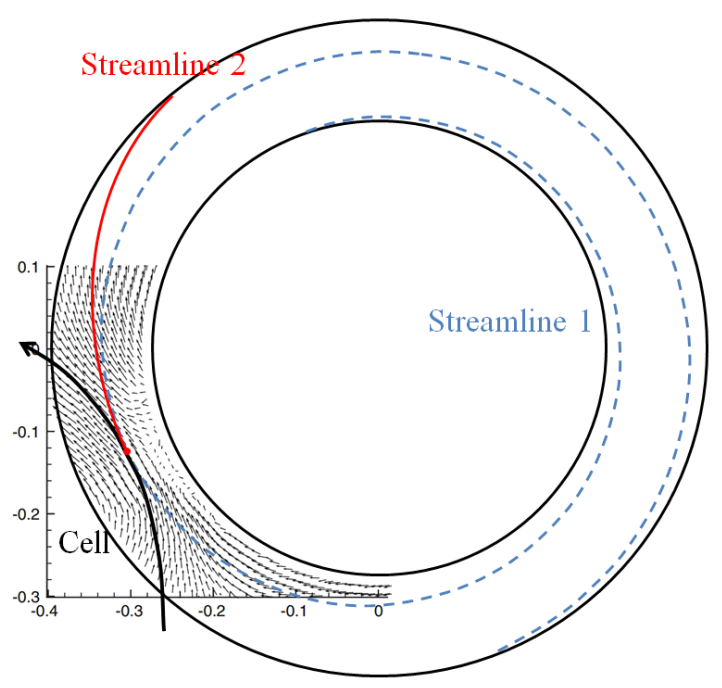

Figure 17 Assumption of the real streamline 


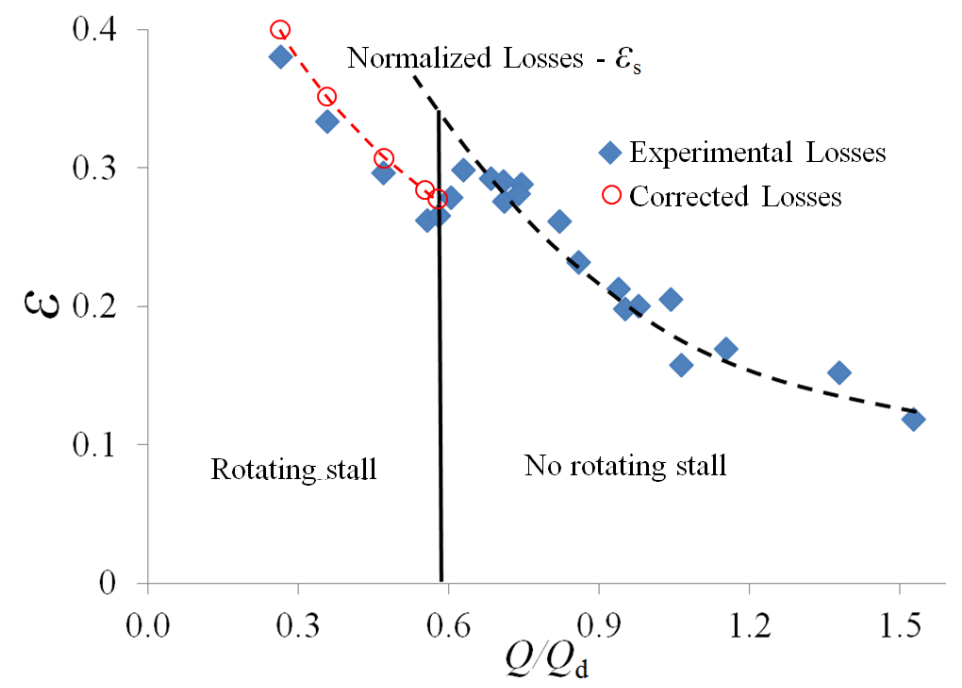

Figure 18 Comparison between experimental losses and corrected losses

In spite of the simplicity of the model, a good agreement is obtained between the corrected loss coefficient and the experimental results, which means that the blockage due to rotating stall cells must be the major cause of the reduction of the losses in unstable operation of the diffuser.

One can nevertheless notice that the corrected losses are a little bit higher than the experimental losses. Therefore, a second explanation has also to be considered: pressure which is measured at the diffuser outlet is a time averaged value and considering the topology of cells, it can be seen that they are characterized by regions of inward radial velocity. Consequently, some high pressure flow coming from downstream of the diffuser (the ambient air at atmospheric pressure) is convected in the diffuser (Fig. 19), then the measured time averaged pressure is actually increased. Eventually, this effect results in the decrease of experimental losses again.

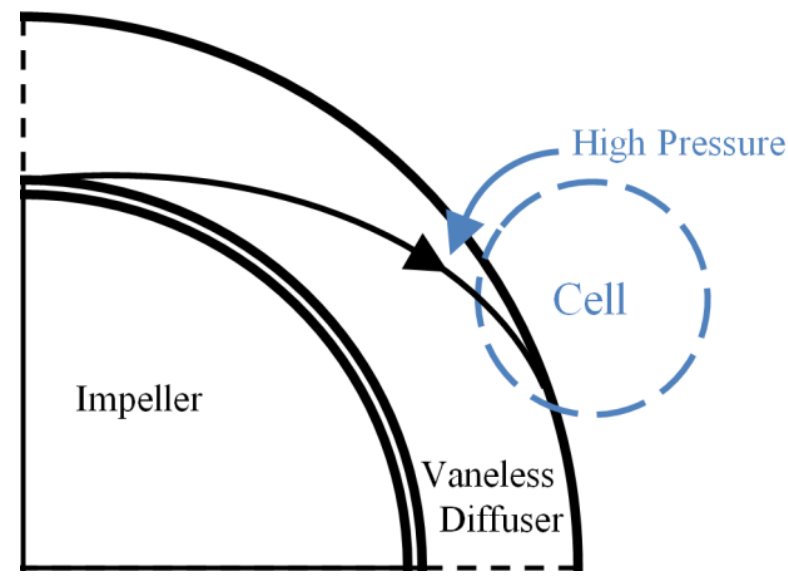

Figure 19 Convection at the diffuser outlet 


\section{Conclusions}

The rotating stall in a vaneless diffuser was experimentally observed and characterized by a dedicated spectrum analysis. Moreover, the pressure recovery in the vaneless diffuser was calculated experimentally and theoretically. By a theoretical assumption, the effect of rotating stall on the diffuser performance was then determined and analyzed. Several conclusions were drawn as follows:

(1) 22 flow rates were tested in experiment, and rotating stall was observed at 5 partial flow rates lower than $Q / Q_{\mathrm{d}}=0.58$. It was found that the dominant stall mode was characterized by 4 cells at $Q / Q_{\mathrm{d}}=0.47,0.56,0.58,2$ cells at $Q / Q_{\mathrm{d}}=0.36$ and 3 cells at $Q / Q_{\mathrm{d}}=0.26$. Moreover, the experimental result shows that the occurrence and characteristics of rotating stalls are the same for the two rotating speed investigated.

(2) In some cases, several competitive stall modes could co-exist intermittently. In this situation, it seems that the mode with fewer cells propagates faster than the mode with more cells.

(3) The effect of rotating stall on the vaneless diffuser performance was analyzed. The result shows that, for operating points with no rotating stall, the losses increase linearly with the length of the streamline in the diffuser. But, it has also been observed that the development of rotating stall is corresponding to an increase of the pressure recovery in the diffuser and to a decrease of the losses compared to a case without rotating stall. The arising of instability has thus a positive effect on the diffuser performance. Two possible reasons were offered: 1 . the shorter length of streamline, due to the blockage induced by the stall cells decreased the friction losses; 2. The convection of some high pressure flow coming from downstream of the vaneless diffuser.

\section{Acknowledgement}

The authors acknowledge the cooperation with the projects: National Natural Science Foundation of China (No. 51509108) and Natural Science Foundation of Jiangsu Province (Grant No. BK20150506). The authors would also like to thank Professor Gerard Bois for the interesting discussions on this topic.

\section{Funding}

The authors wish to thank the financial support by CSC (China Scholarship Council).

\section{Notation}


$B_{3}=$ Diffuser width (mm)

$D=$ Diameter $(\mathrm{mm})$

$D_{1}=$ Impeller inlet diameter $(\mathrm{mm})$

$D_{2}=$ Impeller outlet diameter $(\mathrm{mm})$

$D_{3}=$ Diffuser inlet diameter $(\mathrm{mm})$

$D_{4}=$ Diffuser outlet diameter $(\mathrm{mm})$

$D_{\mathrm{H}}=$ Hydraulic diameter $(\mathrm{mm})$

$f=$ Frequency $(\mathrm{Hz})$

$f_{\mathrm{rs}}=$ Frequency of the dominant stall mode $(\mathrm{Hz})$

$f_{\text {imp }}=$ Impeller frequency $(\mathrm{Hz})$

$L=$ Length of streamline (mm)

$n=$ Number of stall cell (-)

$P=$ Pressure $(\mathrm{Pa})$

$P_{3}=$ Diffuser inlet static pressure $(\mathrm{Pa})$

$P_{4}=$ Diffuser outlet static pressure $(\mathrm{Pa})$

$P_{4 \text { is }}=$ Isentropic diffuser outlet static pressure (Pa)

$Q=$ Flow rate $\left(\mathrm{m}^{3} \mathrm{~s}^{-1}\right)$

$Q_{\mathrm{d}}=$ Design flow rate $\left(\mathrm{m}^{3} \mathrm{~s}^{-1}\right)$

$R=$ Radius $(\mathrm{mm})$

$R_{3}=$ Diffuser inlet radius $(\mathrm{mm})$

$R_{4}=$ Diffuser outlet radius (mm)

$U_{2}=$ Circumferential velocity at impeller outlet $\left(\mathrm{m} \mathrm{s}^{-1}\right)$

$V_{3}=$ Absolute velocity at diffuser inlet $\left(\mathrm{m} \mathrm{s}^{-1}\right)$

$V_{\theta 3}=$ Tangential velocity at diffuser inlet $\left(\mathrm{m} \mathrm{s}^{-1}\right)$

$Z=$ Impeller blade number (-)

$\alpha=$ Flow angle $\left({ }^{\circ}\right)$

$\beta_{2}=$ Blade angle $\left(^{\circ}\right)$

$\omega=$ Circumferential velocity of stall cells $\left(\mathrm{rad} \mathrm{s}^{-1}\right)$ 
$\lambda=$ Friction factor $(-)$

$\rho=$ Density $\left(\mathrm{kg} \mathrm{m}^{-3}\right)$

$\varepsilon=$ Loss coefficient (-)

$\varepsilon_{s}=$ Loss coefficient for stable conditions (-)

\section{References}

[1] Abdelhamid, A. N. (1980). Analysis of Rotating Stall in Vaneless Diffusers of Centrifugal Compressors. ASME 1980 International Gas Turbine Conference and Products Show, Paper No: 80-GT-184, pp. V01BT02A089, 8 pages. New Orleans, USA. doi: 10.1115/80GT-184.

[2] Abdelhamid, A. N. (1981). Effects of vaneless diffuser geometry on flow instability in centrifugal compressor systems. ASME 1981 International Gas Turbine Conference and Products Show, Paper No: 81-GT-10, pp. V001T03A008; 6 pages. Houston, USA. doi: 10.1115/81-GT-10.

[3] Abdelhamid, A. N., \& Bertrand, J. (1979). Distinction between two types of self-excited gas oscillations in vaneless radial diffusers. ASME 1979 International Gas Turbine Conference and Exhibit and Solar Energy Conference, Paper No: 79-GT-58, pp. V01AT01A058, 12 pages. San Diego, USA. doi:10.1115/79-GT-58.

[4] Abdelhamid, A. N., Colwill, W. H., \& Barrows, J. F. (1979). Experimental investigation of unsteady phenomena in vaneless radial diffusers. Journal of engineering for power, 101(1), 52-60.

[5] Abidogun, K. B. (2006). Effects of vaneless diffuser geometries on rotating stall. Journal of Propulsion and Power, 22(3), 542-549.

[6] Aungier, R. H. (1993). Aerodynamic Design and Analysis of Vaneless Diffusers and Return Channels. ASME 1993 International Gas Turbine and Aeroengine Congress and Exposition, Paper No: 93-GT-101, pp. V001T03A042; 8 pages. Cincinnati, USA. doi : 10.1115/93-GT-101.

[7] Cellai, A., Ferrara, G., Ferrari, L., Mengoni, C. P., Baldassarre, L. (2003). Experimental investigation and characterization of therotating stall in a high pressure centrifugal compressor, part IV: impeller influence on diffuser stability. ASME 2003 International Joint Power Generation Conference, Paper No: GT2003-38394, pp. 721-728, 8 pages. Atlanta, USA. doi: 10.1115/GT2003-38394.

[8] Caignaert, G., Desmet, B., \& Stevenaert, D. (1982). Experimental investigations on the flow in the impeller of a centrifugal fan. ASME 1982 International Gas Turbine Conference and Exhibit, Paper No: B2-GT-37, pp. V001T01A013, 6 pages. London, UK. 
[9] Dou, H. S. (1991). Investigation of the Prediction of Losses in Radial Vaneless Diffusers. ASME 1991 International Gas Turbine and Aeroengine Congress and Exposition, Paper No. 91-GT-323, pp. V001T01A097; 7 pages. Orlando, USA. doi:10.1115/91-GT-323.

[10] Dou, H. S., \& Mizuki, S. (1998). Analysis of the flow in vaneless diffusers with large width-to-radius ratios. Journal of Turbomachinery, 120(1), 193-201.

[11] Dazin, A., Cavazzini, G., Pavesi, G., Dupont, P., Coudert, S., Ardizzon, G., Caignaert, G., Bois, G. (2011). High-speed stereoscopic PIV study of rotating instabilities in a radial vaneless diffuser. Experiments in Fluids, 51, 83-93.

[12] Dazin, A., Coudert, S., Dupont, P., Caignaert, G., Bois, G. (2008). Rotating instability in the vaneless diffuser of a radial flow pump. Journal of Thermal Science, 17(4), 368-374.

[13] Fringe, P., \& Van den Braembussche, R. (1985). A theoretical model for rotating stall in the vaneless diffuser of a centrifugal compressor. Journal of Engineering for Gas Turbines and Power, 107(2), 507-513.

[14] Ferrara, G., Ferrari, L., \& Baldassarre, L. (2004). Rotating stall in centrifugal compressor vaneless diffuser: experimental analysis of geometrical parameters influence on phenomenon evolution. International Jounal of Rotating Machinery, 10(6), 433-442. doi: 10.1080/10236210490503950.

[15] Jansen, W. (1964). Rotating stall in a radial vaneless diffuser. Journal of Basic Engineering, 86, 750-758.

[16] Kobayshi, H., \& Nishida, H. (1990). A study on the rotating stall of centrifugal compressors (2nd report, effect of vaneless diffuser inlet shape on rotating stall). Transactions of the JSME, Series B, 56(529), 98-103.

[17] Krause, N., Zähringer, K., \& Pap, E. (2005). Time-resolved particle imaging velocimetry for the investigation of rotating stall in a radial pump. Experiments in Fluids, 39, 192201. doi:10.1007/s00348-005-0935-2.

[18] Kurokawa, J., Saha, S. L., Matsui, J., Kitahora, T. (1999). Passive Control of Rotating Stall in a Parallel-Wall Vaneless Diffuser by Radial Grooves. Journal of Fluids Engineering, 122(1), 90-96.

[19] Ljevar, S., de Lange, H. C., \& van Steenhoven, A. A. (2006). Two-dimensional rotating stall analysis in a wide vaneless diffuser. International Journal of Rotating Machinery, Article ID 56420, pp. 1-11. doi:10.115/IJRM/2006/56420.

[20] Ljevar, S. (2007). Rotating stall in wide vaneless diffusers. Eindhoven University of Technology, Netherlands.

[21] Mahdi, M. J., \& Bryan W. K. (2008). Optimal design and operation of irrigation pumping stations using mathematical programming and genetic algorithm (GA). Journal of Hydraulic Research, 46, 237-246. 
[22] Moore, F. K. (1989). Weak rotating flow disturbances in a centrifugal compressor with a vaneless diffuser. Journal of Turbomachinery, 111(4), 442-449.

[23] Nishida, H., \& Kobayshi, H. (1988). A study on the rotating stall of centrifugal compressors (1st report, effect of vaneless diffuser width on rotating stall). Transactions of the JSME, Series B, 54(499), 589-594.

[24] Ötügen, M. V., So, R. M. C., \& Hwang, B. C. (1988). Diffuser stall and rotating zones of separated boundary layer. Experiments in Fluids, 6, 521-533. doi:10.1007/BF00196598

[25] Pavesi, G., Dazin, A., Cavazzini, G., Caignaert, G., Bois, G., Ardizzon, G. (2011). Experimental and numerical investigation of unforced unsteadiness in a vaneless radial diffuser. 9th european conference on turbomachinery-fluid dynamics and thermodynamics, 625-636. Turkey.

[26] Suzuki, S., Ugai, Y., \& Harada, H. (1977). Noise characteristics in partial discharge of centrifugal fans: 1 st report, low-frequency noise due to the rotating stall. Transactions of JSME, 43(372), 3020-26.

[27] Senoo, Y., Kinoshita, Y., \& Ishida, M. (1977). Asymmetric flow in vaneless diffusers of centrifugal blowers. Journal of Fluids Engineering, 99 (1), 104-111. doi:10.1115/1.3448501.

[28] Senoo, Y., \& Kinoshita, Y. (1977). Influence of inlet flow conditions and geometries of centrifugal vaneless diffusers on critical flow angle for reverse flow. Journal of Fluids Engineering, 99 (1), 98-102. doi:10.1115/1.3448577.

[29] Tsujimoto, Y., Yoshida, Y., \& Mori, Y. (1996). Study of vaneless diffuser rotating stall based on two dimensional inviscid flow analysis. Journal of Fluids Engineering, 118(1), 123-127. doi:10.1115/1.2817489.

[30] Tsurusaki, H., Imaichi, K., \& Miyake, R. (1987). A Study on the rotating stall in vaneless diffusers of centrifugal fans. (1st report, rotational speeds of stall cells, critical inlet flow angle). JSME International Journal, 30(260), 279-287.

[31] Tsurusaki, H., \& Kinoshita, T. (2000). Flow control of rotating stall in a radial vaneless diffuser. Journal of Fluids Engineering, 123(2), 281-286. doi:10.1115/1.1351174.

[32] Wuibaut, G., Dupont, P., Bois, G., Caignaert, G., Stanislas, M. (2002). PIV Measurements in the impeller and the vaneless diffuser of a radial flow pump in design and off design operating conditions. Journal of Fluids Engineering, 124(3), 791-797. 